\title{
Reply to: Zuravlev et al. (2014) Comment on "An enigmatic, possibly chemosymbiotic, hexactinellid sponge from the early Cambrian of South China"
}

\author{
JOSEPH P. BOTTING and LUCY A. MUIR
}

We welcome the comment by Zhuravlev et al. (2014), as it investigates an alternative interpretation of the fossils described as Decumbispongia yuani (Botting et al. 2013) that we had perhaps dismissed too easily. Their discussion is intriguing, but there are several areas in which their arguments are not entirely compelling.

The differences in preservation from most sponges at the site are entirely consistent with the interpreted difference in body form; a robust, three-dimensional body would induce much greater internal, post-mortem anoxia and resultant mineralisation than the thin, membranous wall with embedded spicules that characterises most sponges in the deposit. Zhuravlev et al. (2014) also suggest that such an abundance of sulphate-reducing bacteria within the tissues of the sponge as we proposed would endanger the organism through auto-pyritisation during life, although they do not consider the differences in chemistry between a metabolically stable, living organism, and a decaying carcass buried in anoxic sediment. As is well known, many living sponges can regulate their internal tissue oxygenation (e.g., Hoffman et al. 2008).

The authors rightly emphasize the differences between our interpretation of Decumbispongia and living hexactinellids. However, there is no reason to suppose that Decumbispongia at all closely resembled living hexactinellids in soft tissue organisation. Indeed, we have recently shown that hexactine-bearing sponges occur in the stem groups of both Hexactinellida and Silicea (Botting and Muir 2013), thereby including a wide diversity of taxa. The unique characteristics of Decumbispongia cannot, therefore, be used to reject a sponge affinity.

The debate centres on the interpretation of the spicules and their arrangement. They are visible on the surfaces of three specimens (not one, as stated by Zhuravlev et al. 2014), although they are clearest in NIGP154191. They are morphologically consistent, and are arranged in a combination of both diagonal and orthogonal orientations, but random angles between these are not seen. Most importantly, the spicules are large relative to the body diameter, and the rays are significantly curved to match the surface. Such organisation is virtually impossible to reconcile with ingested spicules, and is the main reason that we dismissed the hypothesis of coprolites or other trace fossils early in our investigation.

Zhuravlev et al. (2014) mention the similarity of Multivascu- latus and Aulophycus, which have been interpreted as sponges but have since been regarded as trace fossils containing hexactines (McMenamin et al. 2000). Multivasculatus is certainly an enigmatic fossil, but it shows multiple cup-like structures connected by a thin sheet, and does not resemble the Ophiomorpha-like Aulophycus at all (Howell and Van Houten 1940; JPB and LAM, personal observations). The regularity of the limited growth form of Decumbispongia, and of the placement of spicules (of multiple sizes, rather than a selected size range), precludes a trace fossil interpretation.

The overall morphology of Decumbispongia does indeed resemble some of the coprolites that Zhuravlev et al. (2014) draw attention to, but the problems of the curved, surface-parallel spicule rays, and their regular arrangement, still remain. The cololite of the trilobite Bergeroniellus illustrated by Ivantsov et al. (2005) contains a few hexactine spicules, but otherwise shows no similarity to Decumbispongia, being an insubstantial, straight trace along the centre of the axis; only a few spicules are visible, and these are disordered with no clear arrangement. Of the other examples provided for comparison, Zhu et al. (2013) do not record any spicules, while Vannier (2012) record some possible monaxon spicules that were considered to be accidentally ingested with sediment, and then discuss in detail why the other monaxial structures present were probably not spicules. None of these examples resemble the regular organisation of the skeleton on the surface of Decumbispongia.

It is very difficult to interpret the consistently semi-toroid Decumbispongia as a cololite simply due to its curvature, which is presumably why the authors regard the complete and largest specimens (which show the strongest curvature) as coprolitesalthough there is no reason to assume that the specimen showing the best spicule arrangement was not the same shape as the other complete examples. There is a similar arrangement of spicules visible on the surfaces of those specimens that Zhuravlev et al. (2014) interpret as cololites and coprolites, and no clear difference in form, making the separation difficult to justify.

Overall, we do not think that the suggestions of Zhuravlev et al. can adequately explain the specific features of Decumbispongia that led to our interpretation of these specimens as sponges. If they represent the cololites or coprolites of large ecdysozoans, it is also difficult to explain the lack of any evidence for these organisms, despite the presence of bivalved arthropods 
and exquisitely preserved sponges in the deposit (Xiao et al. 2005). Instead, we suggest that an interpretation as sponges should be considered for any similar, spicule-bearing fossils that may otherwise be interpreted as cololites or coprolites. These fossils remain enigmatic, and we welcome the debate as it highlights their peculiar characteristics.

\section{References}

Botting, J.P. and Muir, L.A. 2013. Spicule structure and affinities of the Late Ordovician hexactinellid-like sponge Cyathophycus loydelli from the Llanfawr Mudstones Lagerstätte, Wales. Lethaia 46: 454-469.

Botting, J.P., Muir, L.A., Li, X.-F., and Lin, J.-P. 2013. An enigmatic, possibly chemosymbiotic, hexactinellid sponge from the early Cambrian of South China. Acta Palaeontologica Polonica 58: 641-649.

Hoffman, F., Røy, H., Bayer, K., Hentschel, U., Pfannkuchen, M., Brümmer, F., and de Beer, D. 2008. Oxygen dynamics and transport in the Mediterranean sponge Aplysina aerophoba. Marine Biology 153: 1257-1264.

Howell, B.F. and Van Houten, F.B. 1940. A new sponge from the Cambrian of Wyoming. Bulletin of the Wagner Free Institute of Science 15: 1-8. Ivantsov, A.Yu. [Ivancov, A.Û.], Zhuravlev, A.Yu. [Žuravlev, A.Û.], Krasi- lov, V.A., Leguta, A.V., Mel'nikova, L.M., Urbanek, A., Ushatinskaya, G.T. [Ušatinskaâ, G.T.], and Malakhovskaya, Ya.E. [Malahovskaâ, Â.E.] 2005. Unique Sinsk localities of early Cambrian organisms (Siberian Platform) [in Russian]. Paleontologičeskij Institut, Akademiâ Nauk SSSR, Trudy 284: 1-143.

McMenamin, M.A.S., Debrenne, F., and Zhuravlev, A.Yu. 2000. Early Cambrian Appalachian archaeocyathans: further age constraints from the fauna of New Jersey and Virginia, U.S.A. Geobios 33: 693-708.

Vannier, J. 2012. Gut content as direct indicators for trophic relationships in the Cambrian marine ecosystem. PLOS ONE 7 (12): e52200.

Xiao, S., Hu, J., Yuan, X., Parsley, R.L., and Cao, R. 2005. Articulated sponges from the Early Cambrian Hetang Formation in southern Anhui, South China: their age and implications for early evolution of sponges. Palaeogeography, Palaeoclimatology, Palaeoecology 220: 89-117.

Zhu, X., Lerosey-Aubril, R., and Esteve, J. 2013. Gut content fossilization and evidence for detritus feeding habits in an enrolled trilobite from the Cambrian of China. Lethaia 47: 66-76.

Zhuravlev, A.Yu., Vintaned, J.A.G., and Tabachnik, K.R. 2014. Comment on "An enigmatic, possibly chemosymbiotic, hexactinellid sponge from the early Cambrian of South China" by Joseph P. Botting, Lucy A. Muir, Xiangfeng Li, and Jih-Pai Lin. Acta Palaeontologica Polonica 59 (2): 475-476.

Joseph P. Botting [acutipuerilis@yahoo.co.uk] and Lucy A. Muir [lucy@asoldasthehills.org],4 White Heather, Western Promenade,Lladrindod LD1 $5 H R, U K$.

Received 22 February 2014, accepted 31 March 2014, available online 11 June 2014.

Copyright (C 2014 J.P. Botting and L.A. Muir. This is an open-access article distributed under the terms of the Creative Commons Attribution License, which permits unrestricted use, distribution, and reproduction in any medium, provided the original author and source are credited. 